\title{
Productive longevity of white-and-black cows of different genotypes CSN3 and DGAT1
}

\author{
Radik Shaidullin ${ }^{1, *}$, Gazimzyan Sharafutdinov ${ }^{1}$, Anastasia Moskvicheva ${ }^{1}$, Rustam Ravilov², and Ismagil Khakimov ${ }^{3}$ \\ ${ }^{1}$ Kazan State Agrarian University, Kazan 420015, Russia \\ ${ }^{2}$ Kazan State Academy of Veterinary Medicine named after N.E. Bauman, Kazan 420029, Russia \\ ${ }^{3}$ Samara State Agrarian University, Kinel 446442, Samara region, Russia
}

\begin{abstract}
The article studies the duration of use and life-long productivity black-motley breed cows with different allelic variants of the kappa-casein and diacylglycerol O-acyltransferase genes. The research consists the data study on cows dropped out the herd during 2012-2016 in the Dusym LLC of Atninsky District in the Republic of Tatarstan. The cows were previously genotyped for CSN3 and DGAT1. The herd of black-and-white cattle consisted the genotypes CSN3 AA and DGAT1 AK with a frequency of 60.9 and $53.5 \%$ and less often CSN3 BB and DGAT1 KK - 4.0 and $6.3 \%$. Moreover, the frequency of occurrence of the desired B allele of the CSN3 gene was 0.22 , and the $\mathrm{K}$ allele of DGAT1 was 0.33 . Cows with the CSN3 AB genotype reliably surpass animals with the CSN3 AA genotype in the duration of use by 0.39 lactations ( $\mathrm{P}<0.05)$, life-long milk yield by $2401 \mathrm{~kg}$ of milk $(\mathrm{P}<0.05)$, and the amount of milk fat by $90 \mathrm{~kg}$ ( $\mathrm{P}<0.05)$, mass fraction of protein in milk - by $0.04 \%$ ( $\mathrm{P}<0.01)$, the amount of milk protein - by $83 \mathrm{~kg}$ ( $\mathrm{P}<0.05)$. Animals with the DGAT1 KK genotype also have an excess over other groups of cows in terms of productive longevity, but the difference is significant only in fat milk $(\mathrm{P}<0.01-0.001)$.
\end{abstract}

\section{Introduction}

The dairy cattle longevity is considered one of the most important signs ensuring its high lifelong milk productivity, therefore, an important estimate of the cattle is the quantity and quality of the products the cattle gives over the period of economic use.

The results of different studies on the assessment of the cows' productive longevity are still quite contradictory. However, the importance of this issue is noted both from a selection and an economic point of view. As you know, the main factors affecting the duration of the cows' productive longevity in any breeding system include age at the time of the first calving and the degree of milking, including up to record heifers' productivity. Undoubtedly, one of the main factors affecting the duration of economic use is the level of feeding and the balance of diets in terms of nutrition, protein content, macro- and microelements [1-3].

At the same time, along with the indicated general factors, the genetic characteristics of the bulls have a significant impact on the cows' productive longevity.

Studies of many scientists have established a high dependence of the productive longevity of cows on the hereditary characteristics of fathers, rather than on their pedigree and linear affiliation [4-8].

The search for candidate genes (kappa-casein and diacylglycerol O-acyltransferase, etc.), their analysis and the study of the effect of polymorphic variants of such genes on the productivity and longevity of animals is an important task of modern animal husbandry [9-11].

All the above indicates the importance of studying the effect of polymorphism of the kappa-casein and diacylglycerol O-acyltransferase genes on milk productivity and longevity, which can ultimately be used in breeding of dairy cattle.

The aim of the work was to study the duration of use and lifelong productivity of white and black cows, depending on various genotypic factors and, especially, allelic variants of the kappa-casein and diacylglycerol $\mathrm{O}$ acyltransferase genes.

\section{Materials and methods}

In order to study the degree of influence of various factors on the duration of use and lifelong milk yield of cows, the proportion of each of them was determined by the method of one-way analysis of variance. The following factors were taken into account: the origin (selection) of servicing bulls, linear affiliation, genotypes of kappa-casein and diacylglycerol O-acyltransferase.

The research of the use duration and lifelong productivity of dairy cattle consists the data study on black and white cows dropped out the herd in 2012-2016 in Dusym LLC of Atninsky District of the Republic of Tatarstan. The cows were previously genotyped for two

\footnotetext{
* Corresponding author: tppi-kgau@bk.ru
} 
genes for kappa-casein and diacylglycerol $\mathrm{O}$ acyltransferase.

The venous blood of animals used as a material for molecular DNA testing. DNA was extracted using the Magnosorb kit (Interlabservis, Moscow), according to the manufacturer's instructions. The CSN3 gene was studied by polymerase chain reaction followed by restriction fragment length polymorphism (PCR-RFLP) analysis using the direct primer 5'ATAGCCAAATATATCCCAATTCAGT-3 'and the reverse primer 5'-TTTATTAATAAGTCCATGAATCTTG-3' [12] a forward primer 5'-GCTGCTCCTGAGGGCCCTTCG-3 'and reverse primer 5'-GCGGCGGCACTTCATGACCCT-3' [13].

Amplification of the primers was performed on a DT-96 detection amplifier (Russia) according to the following program: for the CSN3 gene fragment, the first cycle is $95{ }^{\circ} \mathrm{C}, 5 \mathrm{~min}$; the next 35 cycles: denaturation $-30 \mathrm{~s}$ at $95{ }^{\circ} \mathrm{C}$, annealing $-50 \mathrm{~s}$ at $63{ }^{\circ} \mathrm{C}$, synthesis $-30 \mathrm{~s}$ at $72{ }^{\circ} \mathrm{C}$; elongation $-5 \mathrm{~min}$ at $72{ }^{\circ} \mathrm{C}$; for the DGAT1 gene fragment, the first cycle is $95{ }^{\circ} \mathrm{C}$, $5 \mathrm{~min}$; subsequent 35 cycles: denaturation $-30 \mathrm{~s}$ at $95{ }^{\circ} \mathrm{C}$, annealing $-30 \mathrm{~s}$ at $57^{\circ} \mathrm{C}$, synthesis $-45 \mathrm{~s}$ at $72{ }^{\circ} \mathrm{C}$; elongation $-7 \mathrm{~min}$ at $72{ }^{\circ} \mathrm{C}$.

The resulting amplicons were subjected to restriction using restriction enzymes Eae I (gene DGAT1) and Hinf III (gene CSN3). The PCR product was evaluated by horizontal electrophoresis in a $2.5 \%$ agarose gel.

The frequency of occurrence of genotypes was determined by the formula:

$$
P=\frac{n}{N}
$$

where $\mathrm{P}$ is the frequency of a genotype;

$n$ is the number of individuals having a certain genotype;

$\mathrm{N}$ is the total number of individuals.

The frequency of individual alleles was determined according to the following formulas [19]:

$$
\begin{aligned}
P_{A} & =\frac{(2 n A A+n A B)}{2 N}, \\
Q_{B} & =\frac{(2 n B B+n A B)}{2 N},
\end{aligned}
$$

$P_{A}$ stands for the frequency of the allele A,

$Q_{B-}$ the frequency of the allele B,

$2 N$ - the total number of alleles.

According to Hardy-Weinberg's law, the expected results of the frequencies of genotypes in the studied population were calculated.

The materials obtained were statistically processed with the calculation of the arithmetic mean (M) and the arithmetic mean error (m) using a computer and using the Microsoft Excel software application from the Microsoft Office 2007 software package. The level of reliability of the results was determined by the Student criterion.

\section{Results}

To fully characterize the bulls, we have studied the productive longevity of the daughter cows, depending on the origin of the servicing bulls.

From the data in table 1, it can be seen that among the analyzed groups of cows, the daughters of the bulls of Canadian breeding have the most productive longevity. They reliably ( $\mathrm{P}<0.05-0.001)$ surpass other groups of animals by the duration of use by $0.57-1.06$ lactations, life-long milk yield by 5583-7749 kg and milk yield per 1 day of life by $1.1-2.1 \mathrm{~kg}$ of milk.

High butterfat content was found in the daughters of the bulls of German breeding $-3.82 \%$. The difference is significant when compared with animals of Hungarian selection $-0.09 \%(\mathrm{P}<0.05)$.

The highest yield of milk fat for the entire period of use was received from first-calf heifers of Canadian origin. It amounted to $695 \mathrm{~kg}$, which exceeds the indicators of other groups of animals by $210-300 \mathrm{~kg}$ (P $<0.01-0.001$ )

Thus, in terms of duration of use and lifetime productivity, the daughters of Canadian breeding bulls were the best.

When characterizing different lines, the hereditary condition of the productive longevity of cows is not always taken into account when assessing the productive qualities of animals. Therefore, we studied the productive qualities and duration of economic use of cows, depending on their linear affiliation.

It has been established that cows belonging to the Reflection Sovering line are characterized by high indicators of productive longevity. At the same time, they surpass animals of other lines by the duration of use by 0.1-0.5 lactations, life-long milk yield by 532-3199 $\mathrm{kg}$ of milk, milk yield per 1 day of lactation - by 0.45 $0.52 \mathrm{~kg}$, for milk yield per 1 day of life $-0.17-0.72 \mathrm{~kg}$ (Table 2).

The lowest values of the indices were observed in the Rokit cows, although the animals of this line have a high mass fraction of fat in milk-3.89\%.

Thus, the evaluation of the lines showed that the cows of the Reflection Sovering line were the best in terms of productive longevity.

Table 1. Productive longevity of the daughters of the bulls of different breeding

\begin{tabular}{|c|c|c|c|c|c|c|}
\hline Breeding & $\mathrm{n}$ & Duration of use, lactations & $\begin{array}{c}\text { Life-long milk } \\
\text { yield, kg }\end{array}$ & Fat, \% & Milk fat, kg & $\begin{array}{c}\text { Yield per 1 day } \\
\text { of life, } \mathrm{kg}\end{array}$ \\
\hline Own reproduction & 76 & $3.24 \pm 0.18$ & $12773 \pm 694$ & $3.80 \pm 0.02$ & $485 \pm 25.6$ & $6.6 \pm 0.21$ \\
\hline Hungarian & 41 & $2.83 \pm 0.27$ & $10607 \pm 934$ & $3.73 \pm 0.03$ & $395 \pm 34.3$ & $5.8 \pm 0.24$ \\
\hline Canadian & 41 & $3.81 \pm 0.33$ & $18356 \pm 1947$ & $3.79 \pm 0.02$ & $695 \pm 73.0$ & $7.9 \pm 0.40$ \\
\hline German & 72 & $2.75 \pm 0.14$ & $12600 \pm 795$ & $3.82 \pm 0.03$ & $481 \pm 30.4$ & $6.8 \pm 0.26$ \\
\hline
\end{tabular}


Table 2. Productive longevity of cows of different lines

\begin{tabular}{|l|c|c|c|c|c|}
\hline \multicolumn{1}{|c|}{ Line } & $\mathrm{n}$ & Duration of use, lactations & $\begin{array}{c}\text { Life-long milk yield, } \\
\mathrm{kg}\end{array}$ & Fat, \% & $\begin{array}{c}\text { Yield per 1 day of } \\
\text { lactation }\end{array}$ \\
\hline Idial & 201 & $3.4 \pm 0.13$ & $16210 \pm 727$ & $3.80 \pm 0.01$ & $16.13 \pm 0.14$ \\
\hline Sovering & 90 & $3.5 \pm 0.19$ & $16742 \pm 1101$ & $3.80 \pm 0.02$ & $16.58 \pm 0.23$ \\
\hline Cheftain & 82 & $3.5 \pm 0.22$ & $15585 \pm 1119$ & $3.80 \pm 0.02$ & $16.06 \pm 0.22$ \\
\hline Rokit & 41 & $3.0 \pm 0.27$ & $13543 \pm 1267$ & $3.89 \pm 0.04$ & $16.11 \pm 0.31$ \\
\hline
\end{tabular}

The first part of the research consist the study of the polymorphism of the kappa-casein gene in black-motley cows. Of the 174 animals, the genotype AA of the kappa-casein gene is $60.9 \%$ (106 goals), the CSN3 AB genotype is $35.1 \%$ (61 goals) and the CSN3 BB genotype is only $4.0 \%$ (7 goals), while the frequency of allele A was 0.78, and that of allele B was 0.22 (Table 3).

Table 3. Kappa-casein gene polymorphism in black-motley cows

\begin{tabular}{|c|c|c|c|c|c|c|c|c|c|c|}
\hline \multirow{3}{*}{$\mathrm{n}$} & \multirow{3}{*}{ 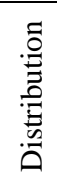 } & \multicolumn{6}{|c|}{$\begin{array}{c}\text { The frequency of CSN3 } \\
\text { genotypes }\end{array}$} & \multicolumn{2}{|c|}{$\begin{array}{l}\text { Allele (gene) } \\
\text { frequency }\end{array}$} & \multirow{3}{*}{$\chi^{2}$} \\
\hline & & \multicolumn{2}{|c|}{$\mathrm{AA}$} & \multicolumn{2}{|c|}{$\mathrm{AB}$} & \multicolumn{2}{|c|}{$\mathrm{BB}$} & \multirow[b]{2}{*}{ A } & \multirow[b]{2}{*}{ B } & \\
\hline & & $\mathrm{n}$ & $\%$ & $\mathrm{n}$ & $\%$ & $\mathrm{n}$ & $\%$ & & & \\
\hline \multirow{2}{*}{174} & $\mathrm{H}$ & 106 & 60.9 & 61 & 35.1 & 7 & 4.0 & \multirow{2}{*}{0.78} & \multirow{2}{*}{0.22} & \multirow{2}{*}{0.14} \\
\hline & $\mathrm{O}$ & 106 & 60.9 & 60 & 34.5 & 8 & 4.6 & & & \\
\hline
\end{tabular}

Note: $\mathrm{H}$ stands for the observed distribution of genotypes;

$\mathrm{O}$ - expected distribution of genotypes

We did not reveal a significant difference between the frequencies of the observed and expected genotypes $(\chi 2=0.14)$, which indicates gene equilibrium in the herd of cows at the locus of the kappa-casein gene.

According to the locus of the diacetylglycerol Oacetyltransferase gene, the study revealed the fact of 70 animals $(40.2 \%)$ out of 174 cattle had the AA genotype, 93 animals $(53.5 \%)$ had the AK genotype and 11 animals or $6.3 \%$ of the CC genotype. The frequency of the allele $\mathrm{A}$ reached 0.67 , and the allele $\mathrm{K}-0.33$ (Table 4).

Table 4. Polymorphism of the diacetylglycerol $\mathrm{O}$-acetyltransferase gene in black and white cows

\begin{tabular}{|c|c|c|c|c|c|c|c|c|c|c|}
\hline \multirow{3}{*}{$\mathrm{n}$} & \multirow{3}{*}{$\begin{array}{l}0 \\
.0 \\
0 \\
0 \\
.0 \\
0 \\
0\end{array}$} & \multicolumn{6}{|c|}{$\begin{array}{l}\text { The frequency of DGAT1 } \\
\text { genotypes }\end{array}$} & \multicolumn{2}{|c|}{$\begin{array}{l}\text { Allele (gene) } \\
\text { frequency }\end{array}$} & \\
\hline & & \multicolumn{2}{|c|}{ AA } & \multicolumn{2}{|c|}{$\mathrm{AK}$} & \multicolumn{2}{|c|}{ KK } & \multirow{2}{*}{ A } & \multirow{2}{*}{ K } & \\
\hline & & $\mathrm{N}$ & $\%$ & $\mathrm{n}$ & $\%$ & $\mathrm{n}$ & $\%$ & & & \\
\hline \multirow{2}{*}{174} & $\mathrm{H}$ & 70 & 40.2 & 93 & 53.5 & 11 & 6.3 & \multirow{2}{*}{0.67} & \multirow{2}{*}{0.33} & \\
\hline & $\mathrm{O}$ & 78 & 44.8 & 77 & 44.3 & 19 & 10.9 & & & \\
\hline
\end{tabular}

Note: $\mathrm{H}$ stands for the observed distribution of genotypes;

$\mathrm{O}$ - expected distribution of genotypes

Cows have a significant difference between the observed and expected values of the genotypes frequencies in the direction of the predominance of the DGAT1 AK genotype, therefore, the genetic balance is disturbed $(\chi 2=7.51 ; \mathrm{P}<0.05)$.

The research on the productive longevity of cows of different genotypes showed that cows with the heterozygous genotype CSN3 AB are characterized by high rates of productive longevity (Table 5). At the same time, cattle with the CSN3 AA genotype is significantly superior in terms of use duration by 0.39 lactations ( $\mathrm{P}<0.05)$, life-long milk yield by $2401 \mathrm{~kg}$ of milk $(\mathrm{P}<0.05)$, and the amount of milk fat by $90 \mathrm{~kg}$ $(\mathrm{P}<0.05)$, the mass fraction of protein in milk - by $0.04 \%(\mathrm{P}<0.01)$, the amount of milk protein - by $83 \mathrm{~kg}$ $(\mathrm{P}<0.05)$.

A high average mass fraction of protein over a lifetime is revealed in cows of the CSN3 BB genotype and the difference between homozygous genotypes was significant by $0.08 \%(\mathrm{P}<0.001)$.

Table 5. Duration of use and lifelong productivity of cows with different CSN3 genotypes

\begin{tabular}{|c|c|c|c|}
\hline \multirow{2}{*}{ Indicator } & \multicolumn{3}{|c|}{ Genotype CSN3 } \\
\cline { 2 - 4 } & $\mathrm{AA}$ & $\mathrm{AB}$ & $\mathrm{BB}$ \\
\hline $\mathrm{n}$ & 106 & 61 & 7 \\
\hline $\begin{array}{c}\text { Duration of use, } \\
\text { lactation }\end{array}$ & $2.97 \pm 0.10$ & $3.36 \pm 0.12^{*}$ & $3.00 \pm 0.22$ \\
\hline $\begin{array}{c}\text { Lifetime milk } \\
\text { yield, kg }\end{array}$ & $15103 \pm 575$ & $17504 \pm 852^{*}$ & $15578 \pm 1507$ \\
\hline Fat \% & $3.68 \pm 0.01$ & $3.69 \pm 0.01$ & $3.67 \pm 0.04$ \\
\hline Milk fat, kg & $556 \pm 21.3$ & $646 \pm 32.0^{*}$ & $571 \pm 58.1$ \\
\hline Protein, \% & $3.12 \pm 0.01$ & $3.16 \pm 0.01^{* *}$ & $3.20 \pm 0.02$ \\
\hline Milk protein, kg & $470 \pm 17.9$ & $553 \pm 26.7^{*}$ & $498 \pm 48.8$ \\
\hline $\begin{array}{c}\text { Milk yield per 1 } \\
\text { day of life, kg }\end{array}$ & $7.98 \pm 0.51$ & $8.26 \pm 0.21$ & $8.24 \pm 0.55$ \\
\hline
\end{tabular}

Note: $*-\mathrm{P}<0.05 ; * *-\mathrm{P}<0.01 ; * * *-\mathrm{P}<0.001$

The indicator characterizing the potential possibilities of cows is also milk yield for 1 day of the animal's life, which is associated with the age of the first calving. When analyzing the herd for milk per 1 day of life, the distribution of productivity is preserved same way as for life-long milk, i.e. data indicate the same trend of superiority in animals with the CSN3 AB genotype $(8.26 \mathrm{~kg})$.

The studies by E.G. Medvedeva, V.I. Tsys [14], L.A. Tanana [15] have shown similar results noting an increase of the use duration and lifelong productivity in cattle with the kappa-casein allele B in the genome.

Cows with the DGAT1 CC genotype exceed the other experimental groups of animals by the use duration by $0.25-0.28$ lactations, life-long milk yield by $314-334 \mathrm{~kg}$ of milk, the mass fraction of fat by $0.07-0.1 \%$, the amount of milk fat - by $23-30 \mathrm{~kg}$, the mass fraction of protein - by $0.04 \%$, the amount of milk protein - by $10-17 \mathrm{~kg}$, but the difference is significant only in butterfat $(\mathrm{P}<0.01-0.001)$ (Table 6). 
Table 6. Duration of use and lifelong productivity of cows of different DGAT1 genotypes.

\begin{tabular}{|c|c|c|c|}
\hline \multirow{2}{*}{ Indicator } & \multicolumn{3}{|c|}{ Genotype DGAT1 } \\
\cline { 2 - 4 } & $\mathrm{AA}$ & $\mathrm{AK}$ & $\mathrm{KK}$ \\
\hline $\mathrm{n}$ & 70 & 93 & 11 \\
\hline $\begin{array}{c}\text { Duration of use, } \\
\text { lactation }\end{array}$ & $3.11 \pm 0.11$ & $3.08 \pm 0.10$ & $3.36 \pm 0.28$ \\
\hline $\begin{array}{c}\text { Lifetime milk } \\
\text { yield, kg }\end{array}$ & $15926 \pm 740$ & $15946 \pm 661$ & $16260 \pm 1582$ \\
\hline Fat \% & $3.66 \pm 0.01$ & $3.69 \pm 0.01$ & $3.76 \pm 0.02 * * *$ \\
\hline Milk fat, kg & $581 \pm 27.4$ & $588 \pm 24.8$ & $611 \pm 59.0$ \\
\hline Protein, \% & $3.11 \pm 0.10$ & $3.15 \pm 0.10$ & $3.15 \pm 0.03$ \\
\hline Milk protein, kg & $495 \pm 23.1$ & $502 \pm 20.7$ & $512 \pm 51.1$ \\
\hline $\begin{array}{c}\text { Milk yield per 1 } \\
\text { day of life, } \mathrm{kg}\end{array}$ & $8.41 \pm 0.77$ & $7.83 \pm 0.16$ & $8.11 \pm 0.49$ \\
\multicolumn{3}{|c|}{ Note: $*-\mathrm{P}<0.05 ; * *-\mathrm{P}<0.01 ; * * *-\mathrm{P}<0.001$} \\
\hline
\end{tabular}

It should be noted that for milk yield on 1 day of life, animals with the DGAT1 AA genotype have an advantage of $0.30-0.58 \mathrm{~kg}$ of milk. When considering the strength and reliability of the impact of genotypic factors on the productive longevity of cows, it was found that the origin of the servicing bulls had the greatest influence, while in terms of longevity it amounted to $19.1 \%(\mathrm{~F}=3.6 ; \mathrm{P}<0.001)$, by life-long milk yield $13.3 \%(\mathrm{~F}=2.9 ; \mathrm{P}<0.05)$ (Table 7$)$.

Table 7. The share and reliability of the influence of various factors on the longevity and life-long milk yield of cows

\begin{tabular}{|c|l|c|c|c|c|}
\hline \multirow{2}{*}{ No } & \multirow{2}{*}{ Factor } & \multicolumn{2}{|c|}{ Duration of use } & \multicolumn{2}{c|}{$\begin{array}{c}\text { Lifetime milk } \\
\text { yield }\end{array}$} \\
\cline { 3 - 6 } & & $\eta^{2}, \%$ & $\mathrm{~F}_{\text {actual }}$ & $\eta^{2}, \%$ & $\mathrm{~F}_{\text {actual }}$ \\
\hline 1 & $\begin{array}{l}\text { Origin of the } \\
\text { servicing bulls }\end{array}$ & 19.1 & $3.6 * * *$ & 13.3 & $2.9^{*}$ \\
\hline 2 & Linear affiliation & 12.4 & $6.1 * * *$ & 10.3 & $5.7 * * *$ \\
\hline 3 & CSN3 genotype & 3.1 & 2.9 & 2.5 & 2.1 \\
\hline 4 & DGAT1 genotype & 3.8 & 3.4 & 6.2 & $4.5^{*}$ \\
\hline
\end{tabular}

Note: $*-\mathrm{P}<0.05$; ** $-\mathrm{P}<0.01 ; * * *-\mathrm{P}<0.001$

A reliable and high degree of influence of linear affiliation on the duration of use is set within $\eta^{2}=12.4 \%$ $(\mathrm{F}=6.1 ; \mathrm{P}<0.001)$, on lifetime milk yield $-10.3 \%(\mathrm{~F}=$ $5.7 ; \mathrm{P}<0.01)$.

Of the DNA markers, the DGAT1 genotype had the greatest and most significant effect on lifelong milk yield of cows $-\eta^{2}=6.2 \%(\mathrm{~F}=4.5 ; \mathrm{P}<0.05)$. The share of the influence of the kappa-casein genotype on the indicators of productive longevity was insignificant and amounted to less than $3.1 \%$. Therefore, the CSN3 and DGAT1 genotypes are more associated with milk quality than with productive longevity of cows.

\section{Conclusion}

Thus, we can conclude:

1. The calculations using the Hardy-Weinberg formulas and the $\chi^{2}$ method showed the highest frequency of occurrence of the CSN3 genotypes (60.9 $\%)$ of the dairy herd, DGAT1 AK $(53.5 \%)$ and there is a shift in genetic equilibrium towards the DGAT1 AK genotype. Therefore, dairy cattle of Dusym LLC of the Atninsky District undergoes artificial selection at the locus of the diacetylglycerol O-acetyltransferase gene.

2. Cows with the genotype $A B$ of the kappa-casein gene and $\mathrm{KK}$ of the diacylglycerol $\mathrm{O}$-acyltransferase gene are characterized by both long-term economic use and high lifelong productivity.

3. The origin of the servicing bulls had the strongest and most reliable effect on the duration of use and lifelong milk yield of cows of different genotypes.

\section{References}

1. H. Valitov, S. Karamaev, Productive longevity of cows in conditions of intensive milk production technology (Samara, 2012)

2. V. Leonov, Zootechnics 1, 6-8 (2012)

3. G. Serdyuk, Dairy and beef cattle breeding 6, 7-10 (2015)

4. G. Kalievskaya, Dairy and beef cattle breeding 5, 25-28 (2002)

5. S. Karamaev, Zootechnics 5, 16-19 (2009)

6. H. Kuchakov, Breeding, feeding, keeping livestock and livestock production technology 5, 50-52 (1998)

7. G. Sharafutdinov, R. Shaidullin, Sci. notes of the Kazan State Academy of Veterinary Medicine 202, 226-230 (2010)

8. M. Polasek, V. Cermak, J. Riha, Buku Zivocis na Vuroba 7, 585-594 (1990)

9. A. Petrov, A. Galstyan, I. Radaeva, S. Turovskaya et al., Foods and Raw Materials 2, 151-161 (2017) Retrieved from: https://doi.org/10.21603/2308-4057 -2017-2-151-161

10. J. Szyda, M. Morek-Kopec, J. Komisarek, A. Zarnecki, BMC Genetics 12, 30 (2011) Retrieved from: https://doi.org/10.1186/1471-2156-12-30

11. R. Vafin, S. Tyulkin, L. Zagidullin et al., Res. J. of Pharmaceutical, Biological and Chemical Sci. 2, 2075-2080 (2016)

12. L. Kalashnikova, I. Dunin, V. Glazko et al., DNA technology for assessing farm animals (Forest Glades, VNIIplem, 1999) 
13. R. Slepman, C. Ford, P. McEihinney, G. Gregory, R. Shell, J. of Dairy Sci. 85, 3514-3517 (2002)

14. E. Medvedeva, V. Tsys, Bull. of the AIC of the Upper Volga Region 3(3), 18-20 (2008)
15. L. Tanana, Use of DNA testing for the CSN3 gene in breeding dairy cattle (Grodno, 2014) 